\title{
Function of Project Manager and Officer
}

\author{
Momin Mukherjee
}

\begin{abstract}
Construction of any projects brings the different degrees of environmental change and change of people also not limited to construction. Therefore, the project definition may be reset the boundaries, or subject to various expectations and interpretations by different stakeholders which are discussed briefly in this paper. The project opportunities may benefit from the practice of stakeholders' management. Using a systematic judgment and participating theory combination will contribute to the theory and practice in managing the project efficiently.
\end{abstract}

\section{Keywords}

Job duties of project officer;

Project management;

Project officer;

Project's plan.

Project scope;

Risk management;

\section{INTRODUCTION}

The initial phase of a project's life cycle is a common source of difficulty in the development process is to complete an incomplete opportunity [1]. Meanwhile, the development of the project can affect the various positive or negative interests [2]. The main empirical question: 'How can the level of completeness of the project opportunity are evaluated in the account for the difference between shareholders for the benefit of a better project results among public disaster projects. The research is being conducted to develop a project that will help in the project planning project partnership phase gradually, with adequate consideration of partners' inputs at the planning stage, with the help of measuring the completeness of the project convection, and this will create a better project results [3]. Literature proposes that the project's scope definition practice and stakeholder management are two separate domains, which are often investigated separately.

Strategies for the improvement of any product quality distribution, organized development and the tools effect the distribution of the different jobs of the project [4]. The diversity of the project features and the environment for the research and development organization, distribution patterns gradually continued among the most popular methods of investigation, the most preferred methods are the most effective. In these paper job duties of project manager, role of project officer is discussed briefly in Section II and Section III respectively.

\section{Job Duties of a Project Manager}

In order to complete a specific project, the project manager will first need to prepare a method of action [5]. Overhead time is scheduled and used to set up a distribution meeting. Successful project to administrative single layer attend the meeting.

The important planning and budget work is to make the project manager additional demand for a particular project [6]. The manager should prepare a report regarding the concern project. The report includes also extra time for specifications to work and description; extra time to adjust management issues among local groups' leaders and project manager. Few important task of the project management is discussed here,

\section{A. Risk Management}

Risk management is one of the main tasks of a project manager. To reduce different risk factors must collect all required information related to project execution. Prediction and proper estimation of the risk is one of the important tasks of the project manager [7]. Regular monitoring of the project and various risk factors is essential to proper documented.

Any critical risk of any scheme is required to monitor periodically and take corrective action as per requirement. Different information collection and monitoring of the project is essential. Sometimes it appears an expensive but it is required for future references for the future important start-up project.

\section{B. Timescales}

The project's detailed tasked is required to schedule in an approximate time scale with proper deadline. The schedule may be based on demand of the project and priority of the each and every individual tasked based on the work. It is an essential duty of the project manager must maintain the work scheduling properly [8]. Usually every task required to complete before each deadline.

\section{Communication}

Project work is a team work. It is important to work together for successful completeness of the project. Proper communication is essential among the team member [9]. All possible problems related to the project directly or indirectly should be discussed with the team, where the project is endangered and helps 
the project manager to make possible solutions [10]. Each and every detail may be required to discuss with co-workers. The report of the work is essential to report in proper hierarchical structure.

\section{Project Meetings}

The manager should arrange meetings frequently among the project members. Recommendation for any additional task, alternation of processed must be approved by the house and manager may be accept the decision or may not depending on the situation.

The project manager frequently reviews the general progress of the work that constantly put input towards successfully complete the project [11]. Regular meeting overcome communication problems. Before the basic arrangements for the particular meeting it is required to organize meeting rooms, refreshments etc. Attendees of the meeting must be note for future reference. Send them to all relevant information, including agendas, papers, presentations and reports to attend to the meeting minutes forwarded to the head of the organization.

\section{E. Documentation}

It is also one important technique used in fact finding. For this process an user or the analyst must visit the organization or the system. It is generally a practical process. The analyst must observe and understand the flowing of documents and also how the system works [12]. Different strategy like work shift, number of the employee, instruments or equipment which are used to complete the project is also necessary to clarify to the management in documented way to avoid future conflict. A track development must be documents in every state, a start-up activity by the individual receiving the board until the final project work. This documentation will keep the project under control of the head of the organization. It will include the filing of documents in the library project to project. The auditor team may check anything that is accurately deposited by the project manager.

\section{Function OF Project OfFicer}

Project manager may appoint project officer when the project load increase upon him [13]. In the case of big project more than one project officer may be appointed. Nowadays the recruitment, development and keeping of talent are very important in all company performance, and if organizations investment in talent management it's not cause to enough and satisfaction to achieve desired level of talent pool [14]. The project officer for that project is to help the project officer to achieve the success of the project remains on them. Teamwork and communication among the different stack holder is an important criterion for successful project management. Different level of the work may vary from one project to another [15]. One can support a project called the assistant project officer and assistant project manager. Project officer also required to show excellent management skills and technical skills. Successful project management skill leads the project towards its complete.

The project officer must keeps a list of potential hazards for each project, paying attention to the danger the document has called them to register [16]. The items listed in the project registers depends on the manager decision, project officer may note additional items apart from them for the betterment of the project. It helps keep under control the cost of the project by observing the problems that need to be built into the floor so that it costs the project minimized [17].

Recommendation for the assistance of the project manager is depended in the two major phases, first phase start-up phase and the project run as soon as possible (primarily during the initial planning plan) for the category of risks and risks identification, monitoring and control of ongoing projects in the second phase for active risk management.

Project office arranges board meeting with members of the project, which is responsible for overall project success [18].

Another important roles of the project officer handle the efficiently in absent of the project manager. In the case of the non arability of the project offer project manager have to do all task of the project officer.

\section{CONCLUSION}

It is a general demand that the project must complete in time and on budget. The project manager frequently reviews the general progress of the work. As an important member of the project team, maintain good relationships with co-workers, understands everyone's work and they are able to complete in time. The future work will include study of the different projects and identify various hazard indicators.

\section{REFERENCES}

[1] Atkinson, R., Crawford, L., \& Ward, S. (2006). Fundamental uncertainties in projects and the scope of project management. International journal of project management, 24(8), 687-698. 
[2] Bonner, J. M., Ruekert, R. W., \& Walker, O. C. (2002). Upper management control of new product development projects and project performance. Journal of Product Innovation Management, 19(3), 233-245.

[3] Roy, A., \& Mukherjee, K. (2017). Entrepreneurial Education in India. International Journal of Advanced Engineering and Management, 2(1), 15-20.

[4] Van der Vorst, J. G., \& Beulens, A. J. (2002). Identifying sources of uncertainty to generate supply chain redesign strategies. International Journal of Physical Distribution \& Logistics Management, 32(6), 409-430.

[5] Wenger, E. C., \& Snyder, W. M. (2000). Communities of practice: The organizational frontier. Harvard business review, 78(1), 139 146.

[6] Pellegrinelli, S. (1997). Programme management: organising project-based change. International Journal of Project Management, 15(3), 141-149.

[7] Barki, H., Rivard, S., \& Talbot, J. (1993). Toward an assessment of software development risk. Journal of management information systems, 10(2), 203-225.

[8] Fui-Hoon Nah, F., Lee-Shang Lau, J., \& Kuang, J. (2001). Critical factors for successful implementation of enterprise systems. Business process management journal, 7(3), 285-296.

[9] Humphrey, W. S. (1988). Characterizing the software process: a maturity framework. IEEE software, 5(2), 73-79.

[10] Veil, C., \& Turner, J. R. (2002). Group efficiency improvement: how to liberate energy in project groups. International Journal of Project Management, 20(2), 137-142.

[11] Von Zedtwitz, M. (2002). Organizational learning through post-project reviews in R\&D. R\&D Management, 32(3), 255-268.

[12] M. Mukherjee(2017). Innovation and System Design. International Journal of Advanced Engineering and Management,2(2) 29-32.

[13] Jaafari, A., \& Manivong, K. (1998). Towards a smart project management information system. International journal of project management, 16(4), 249-265.
[14] Abdollahbeigi, B., Salehi, F., \& Jayashree, S. (2017). The Effect of Recruitment, Selection and Development on Talent Management in IKCO Company in Iran.International Journal of Advanced Engineering and Management, 2(3), 69-77.

[15] Khang, D. B., \& Moe, T. L. (2008). Success criteria and factors for international development projects: A life-cycle-based framework. Project Management Journal, 39(1), 72-84.

[16] Kartam, N. A., Flood, I., \& Koushki, P. (2000). Construction safety in Kuwait: issues, procedures, problems, and recommendations. Safety Science, 36(3), 163-184.

[17] Kahneman, D., Lovallo, D., \& Sibony, O. (2011). Before you make that big decision. Harvard business review, 89(6), 50-60.

[18] Schindler, M., \& Eppler, M. J. (2003). Harvesting project knowledge: a review of project learning methods and success factors. International journal of project management, 21(3), 219-228

\section{Momin Mukherjee}

mmukherjee964@gmail.com

Department of Management and Humanatics,

NIT Arunachal Pradesh, India

Editor in Chief: Sahadev Roy 